\title{
Calcium and reproductive function in the hen
}

\section{By A. B. Gilbert, Agricultural Research Council's Poultry Research Centre, Roslin, Midlothian EH25 $9 P S$, Scotland}

The relationship between nutrition and physiology is intriguing and, when considered closely, may have wider implications than at first thought. To illustrate this statement, I wish to consider, in a representative bird, what may be regarded as a relatively simple dietary constituent.

As in mammals, the domestic hen requires calcium for normal metabolic function and for bone formation during growth. Maintenance requirements are relatively similar to those for mammals and, for both hens and cocks, are $0.1-0.2 \mathrm{~g} / \mathrm{d}$ (Tyler \& Wilcox, 1942; Wilson et al. 1969); for skeletal formation during growth $0.4 \mathrm{~g} / \mathrm{d}$ is adequate (Berg et al. 1964). However, the hen differs from the mammal because reproduction in birds is accomplished through the production of an egg with a calcified shell.

There is now extensive literature on $\mathrm{Ca}$ metabolism, though most concerns the domestic fowl. Much is known of the requirements for $\mathrm{Ca}$, the role of the digestive tract, absorption from the tract, the importance of medullary bone, shell formation and the relationship between dietary $\mathrm{Ca}$ and shell calcification (Taylor \& Moore, 1956; Simkiss, 1961, 1967, 1975; Petersen, 1965; Taylor, 1965, 1970a,b, 1972, 1980; Taylor \& Stringer, 1965; Gilbert, 1967, 1969a; Simkiss \& Taylor, 1971; Clark \& Simkiss, 1980); in particular the endocrinology of $\mathrm{Ca}$ metabolism has been excellently reviewed by Dacke ( 1979 ).

In the majority of past work the emphasis has been placed on the obvious relationship between shell formation and Ca metabolism. Egg production has been given little consideration and in the extreme has been restricted to a fixed term in the equations used to determine dietary requirements (e.g. Petersen, 1965). In contrast, I wish to approach the subject by considering $\mathrm{Ca}$ metabolism within a wider biological framework.

\section{Requirements for $\mathrm{Ca}$ in reproduction}

Modern laying-strains of domestic fowl have a commercial laying life of about 50 weeks, during which time they will produce upwards of $280 \mathrm{eggs}$. The size of the egg depends much on the species (Romanoff \& Romanoff, 1949; Gilbert, 1979). In the domestic hen, egg size ranges from 40 to $70 \mathrm{~g}$ (Romanoff \& Romanoff, 1949), though age, breed, body size, temperature and time of year may affect this. However, most of the eggs produced by the majority of hens fall within the range of $55^{-6} \mathrm{~g}$ (Petersen, 1965 ).

Clearly, a hen which produces an egg weighing approximately $6 \circ \mathrm{g}$ on most days over 50 weeks has a considerable loss of material in reproduction and during this 
time she will void material equivalent to about twelve times her own body-weight (Gilbert, I97 I a). Of more serious concern is the loss to the hen of the $\mathrm{Ca}$ in the egg, of which $99 \%$ is contained in the shell (Petersen, 1965; Gilbert, 1971 b). A typical shell, weighing $5^{-6} \mathrm{~g}$, contains approximately $2 \mathrm{~g} \mathrm{Ca}$ (Petersen, 1965; Gilbert, ${ }_{1971} b$ ). This amount of $\mathrm{Ca}$ is equal to $10 \%$ of the total body $\mathrm{Ca}$ (Taylor, 1965) and thus, in a normal laying year, up to thirty times the hen's own total $\mathrm{Ca}$ is produced as shell.

It is clear that the hen is faced with two directly opposed conditions: she is faced with the drive towards reproduction with the concomitant large loss of $\mathrm{Ca}$, but she must also maintain a positive $\mathrm{Ca}$ balance. It is self-evident that the average daily Ca output $\left(\mathrm{Ca}_{\mathrm{O}}\right)$ cannot exceed the daily input $\left(\mathrm{Ca}_{\mathrm{i}}\right)$ if the bird is to survive:

$$
\mathrm{Ca} i \mathrm{Ca}_{\mathrm{O}}
$$

However, both $\mathrm{Ca}_{\mathbf{i}}$ and $\mathrm{Ca}_{\mathrm{o}}$ have several components (Fig. $\mathrm{I}$ ). Daily input is dependent on the quantity of food eaten $\left(F_{i}\right)$, the $\mathrm{Ca}$ content of the food $(\mathrm{Ct})$ and the relative proportion of the $\mathrm{Ca}$ that can be absorbed from the intestinal contents (Ab). Skeletal or other internal sources of $\mathrm{Ca}(\mathrm{Sk})$ could also be utilized. Thus:

$$
\mathrm{Ca}_{\mathrm{i}}=\left(\mathrm{F}_{\mathrm{i}} \times \frac{\mathrm{Ct}}{100}\right) \frac{\mathrm{Ab}}{100}+\mathrm{Sk}
$$

Similarly, average daily output of $\mathrm{Ca}$ will depend on the number of eggs produced $\left(E_{n}\right)$ over a given time $(t)$, the amount of $\mathrm{Ca}$ in the shell $(\mathrm{Sc})$ and the requirements of $\mathrm{Ca}$ for general metabolism (including that lost in the urine) (M):

$$
\left.C a_{0}=\frac{\left(E_{n}\right.}{t} \times \mathrm{Sc}\right)+M
$$

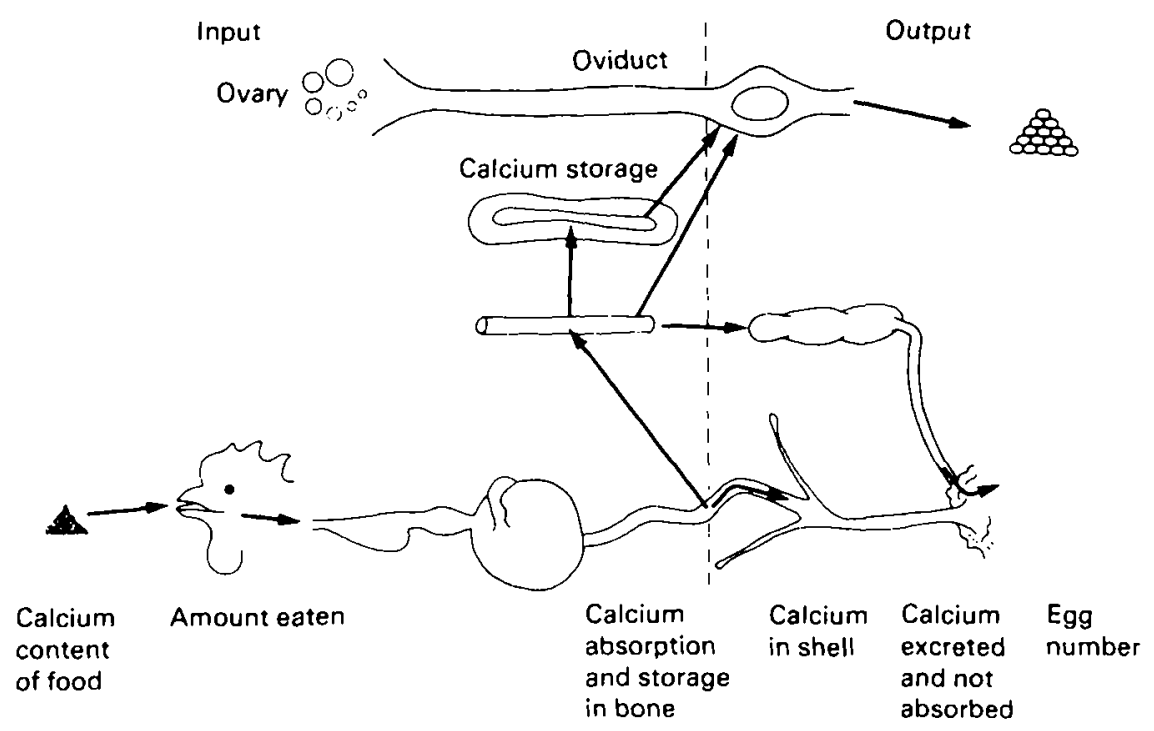

Fig. 1. Calcium metabolism in the laying hen. 
Dietary factors and the supply of $\mathrm{Ca}$

Food intake. Food intake is a major consideration in the supply of $\mathrm{Ca}$, though many factors will affect it, for example, crop size, time available for eating and the requirement for essential nutritional materials (Duncan et al. 1970; Wood-Gush \& Horne, 1970; Savory, 1979). Most of these are not related to the supply of $\mathrm{Ca}$ per se, though when Ca is an integral part of the food, fluctuations in the amount of food consumed will affect the amount of $\mathrm{Ca}$ taken into the digestive tract.

In addition, there is evidence that food intake may be varied daily by the hen specifically to regulate her intake of $\mathrm{Ca}$ in relation to shell formation. With diets containing large amounts of $\mathrm{Ca}$ (approximately $30 \mathrm{~g} / \mathrm{kg}$ ), the quantity of food eaten on days when shell-formation occurs is up to $25 \%$ greater than on days when no shell is being formed (Morris \& Taylor, 1967; Taylor \& Kirkley, 1967; Roland et al. 1972). Also, with hens made to lay shell-less eggs (or supplied with separate calcareous grit) the level of food intake is similar on both egg-forming and non-egg-forming days (Taylor, 1970b, 1972). When food is provided ad lib. much

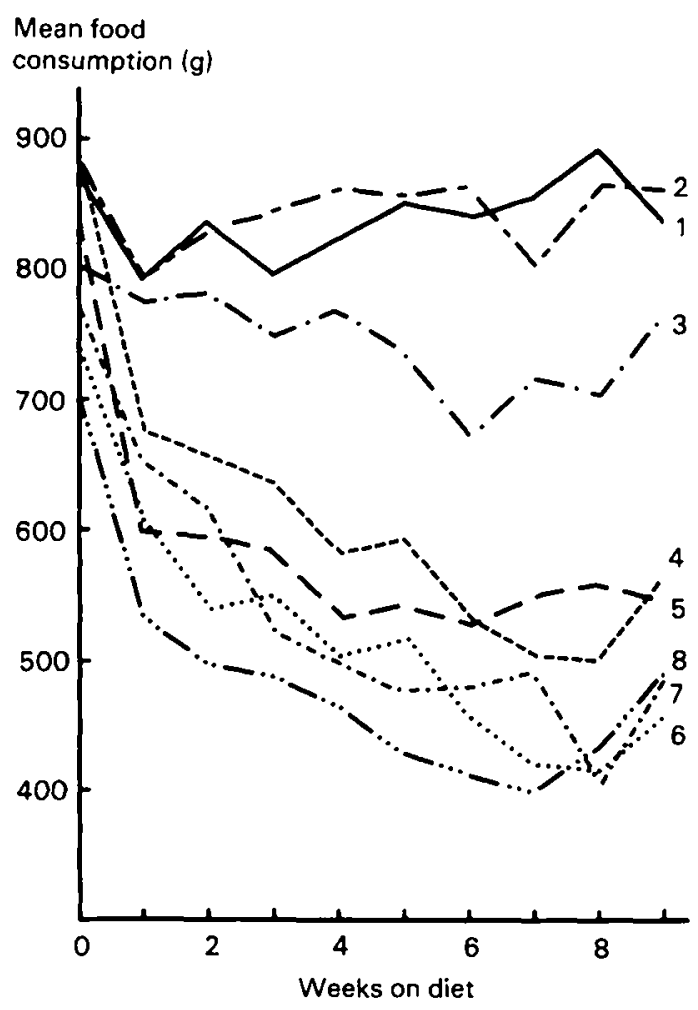

Fig. 2. Average weekly food consumption per bird in relation to the calcium content of the diet.

\begin{tabular}{|c|c|c|c|c|c|c|c|c|}
\hline & & & & Die & nber & & & \\
\hline Ca content $(\mathrm{g} / \mathrm{kg})$ & $\begin{array}{c}I \\
3^{6 \cdot 8} 8\end{array}$ & $\begin{array}{c}2 \\
30.9\end{array}$ & $\begin{array}{c}3 \\
19 \cdot 6\end{array}$ & $\begin{array}{c}4 \\
9 \cdot 7\end{array}$ & $\begin{array}{c}5 \\
5 \cdot 5\end{array}$ & $\begin{array}{c}6 \\
I \cdot 9\end{array}$ & $\begin{array}{c}7 \\
0.96\end{array}$ & $\begin{array}{c}8 \\
0.4^{8}\end{array}$ \\
\hline
\end{tabular}


of the daily intake is consumed by midday, with the remainder being eaten at the end of the day (Savory, 1979, I980). Because active shell formation occurs during the night, it is tempting to suggest that the further act of eating towards the end of the day is to ensure an adequate supply of $\mathrm{Ca}$ in the gut contents while shell formation is actually taking place. This view is supported by the fact that the tendency to eat later in the day is less marked in those hens which are not producing a shell.

However, despite the obvious ability to vary food intake in relation to the need to provide $\mathrm{Ca}$ for actual shell formation, the hen seems unable to utilize an increase in food intake over a long period of time to compensate specifically for a fall in the amount of $\mathrm{Ca}$ in the diet. It would seem reasonable to expect that when $\mathrm{Ca}$ in the diet decreases, food intake would increase, at least within certain limits. Earlier work suggested that this may be so (Hull \& Scott, 1969; Taylor, I970b) but this work is difficult to assess because, in the main, few different levels of Ca were compared and most comparisons were made between diets which would now be regarded as insufficient. Moreover, excessively high levels of $\mathrm{Ca}$ in the diet (over $45 \mathrm{~g} / \mathrm{kg} \mathrm{diet}$ ) may also lead to an abnormally decreased food intake (Hurwitz et al. 1969; Damron \& Harms, 1980) adding further to the difficulties of interpretation. Recently, Gilbert et al. ( 1981), using a homogeneous population of birds and eight dietary levels of $\mathrm{Ca}$, ranging from approximately 0.5 to $3^{6} \mathrm{~g} / \mathrm{kg}$ diet, found food intake to be proportionally related to the level of $\mathrm{Ca}$ in the diet and not inversely related (Fig. 2). Thus, food intake per se does not seem to be used as a mechanism to maintain an optimum intake of $\mathrm{Ca}$ to meet the hen's reproductive needs.

$\mathrm{Ca}$ content of the diet. Apart from their effects on food consumption, dietary levels of $\mathrm{Ca}$ are important in themselves in regulating $\mathrm{Ca}$ intake. Though $\mathrm{Ca}$ is an abundant element in nature, its presence in natural food materials is restricted

\section{Table I. Calcium content of virious naturally-occurring foodstuffs*}

$\begin{array}{lcc}\text { Mean Ca content } & \begin{array}{c}\text { Range } \\ (\mathrm{ppm})\end{array} & \begin{array}{c}\text { (ppm) } \\ \text { Maize }\end{array} \\ \text { Wheat } & 0.02 & 0.01-0.2 \\ \text { Barley } & 0.04 & 0.01-0.42 \\ \text { Oats } & 0.05 & 0.02-0.25 \\ \text { Sorghum } & 0.09 & 0.04-0.18 \\ \text { Soya } & 0.01 & 0.01-0.02 \\ \text { Ground nuts } & 0.25 & 0.16-0.61 \\ \text { Beans } & 0.19 & 0.07-0.46 \\ \text { Grass meal } & 0.09 & 0.05-0.10 \\ \text { Herring meal } & 0.56 & 0.39-1 \cdot 20 \\ \text { Fish meal } & 3.14 & 1.61-5.83 \\ \text { Meat meal } & 6.13 & 3.84-7.70 \\ \text { Rape seed } & 8.36 & 7.30-9.40 \\ & 0.65 & 0.53-0.84\end{array}$

-Though the fish and meat meals are not naturally-occurring substances, they do indicate the likely level of $\mathrm{Ca}$ in animal food materials. These values should be compared with the artificially produced layers' diet containing in excess of $30000 \mathrm{ppm} \mathrm{Ca}$. 
(Table 1). Carnivorous birds feeding on, for example, fish, crustacea or shelled molluscs may have a ready supply of $\mathrm{Ca}$ in their normal diets but for herbivorous or gramnivorous types $\mathrm{Ca}$ is not easily accessible.

For the most part, modern strains of intensively laying domestic hens are given commercially prepared diets which are formulated to contain sufficient $\mathrm{Ca}$ (added as ground limestone) to permit optimum laying when food intake is between 100 and $120 \mathrm{~g} / \mathrm{d}$. Modern recommended values of Ca vary between 30 and $40 \mathrm{~g} / \mathrm{kg}$ diet (Poultry Working Group no. 2 (Nutrition), 1981); the most suitable value is still under debate because too high levels of $\mathrm{Ca}$ in the diet may have adverse effects on egg production (Petersen et al. 1960; Sanford, 1964; Davidson \& Boyne, 1970).

Nevertheless, hens have a specific appetite for Ca (Wood-Gush \& Kare, I966; Mongin, 1970; Hughes \& Wood-Gush, 1971; Hughes, 1972) which may be under control of the parathyroid hormone (Dacke, 1979) (Fig. 3). Thus they will readily consume considerable quantities of mineral $\mathrm{Ca}$ carbonate (up to $17 \mathrm{~g} / \mathrm{d}$ ) in the form of limestone chips or broken oyster shell (Petersen, 1965; Hughes, 1972; Mongin \& Sauveur, 1974). By providing hens with this kind of alternative source of $\mathrm{Ca}$ they will regulate their intake of $\mathrm{Ca}$ in relation to their requirements for the production of a shell independently of their food intake. Thus, more free $\mathrm{Ca}$ is eaten on shell-forming days than when no shell is being formed and much of the $\mathrm{Ca}$ consumption occurs in late afternoon (Petersen, 1965; Taylor, 1970b; Hughes, 1972; Mongin \& Sauveur, 1974). In these cases variation in food intake (see previously) does not occur.

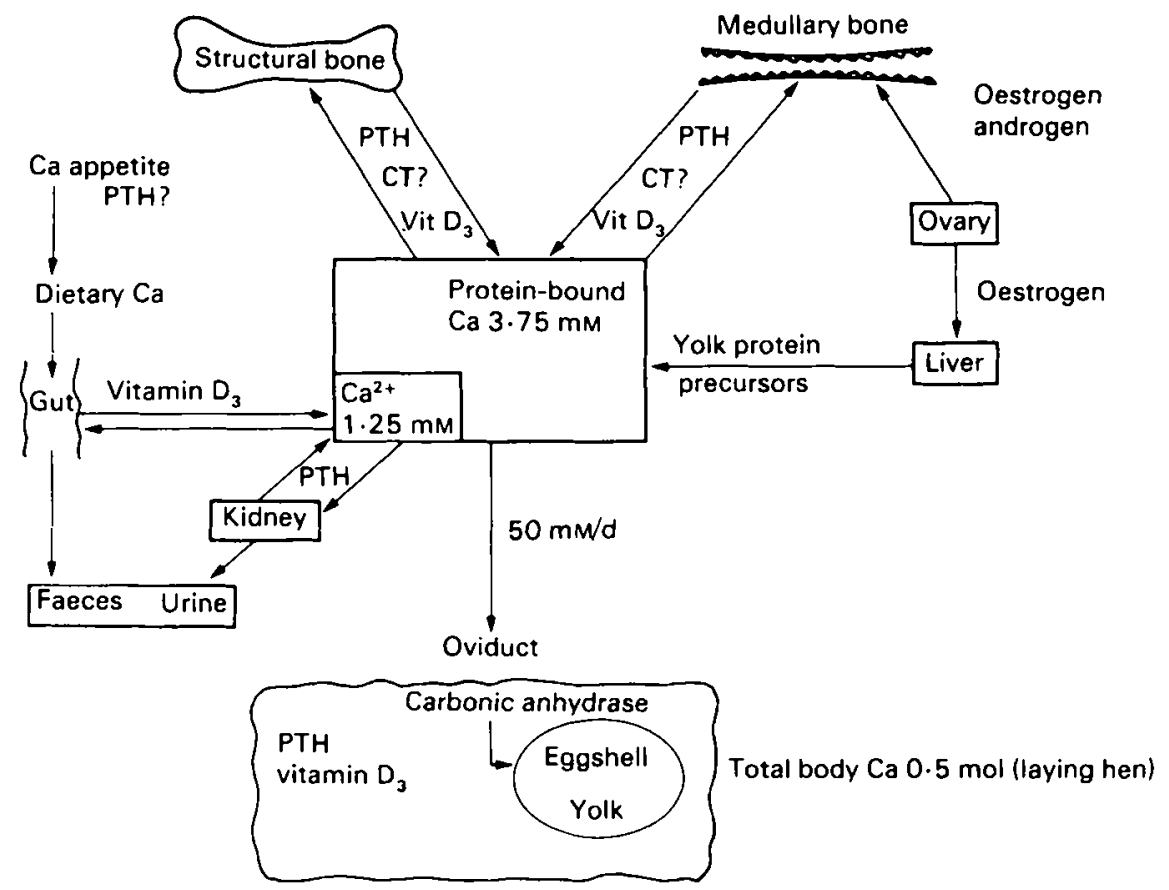

Fig. 3. Endocrinology of calcium metabolism in the laying hen. CT, calcitonin; PTH, parathyroid hormone. Reproduced with permission from Dacke (1979). 
Though this suggests a direct relationship between the intake of mineral $\mathrm{Ca}$ and shell formation, this view may not be entirely valid. Even after shell formation was prevented (by ligating the oviduct or by causing shell-less eggs to be produced), Hughes (1972) found that the increased uptake still occurred and hence suggested it may be related more to ovulation than to the production of a shell.

$\mathrm{Ca}$ absorption from the intestine. The uptake of $\mathrm{Ca}$ occurs mainly in the duodenum and upper jejunum of the hen (Hurwitz et al. 1973; Hurwitz, 1976) and both active and passive mechanisms are present. The active uptake involves a specific Ca-binding protein (CBP) (for reviews see Wasserman \& Taylor, 1973; Wasserman et al. 1974) which is confined mainly to the duodenum and which may operate only when the $\mathrm{Ca}$ in the intestinal contents is low (Simkiss, 1975 ; Hurwitz, 1976; Clark \& Simkiss, I980). Active uptake may, therefore, not be important during normal conditions of shell deposition (Hurwitz, 1976; Mongin, I980; Taylor, 1980), though apparently the activity of both the CBP and the I,25-hydroxycholecalciferol in the intestinal mucosa varies in relation to shell calcification. Vitamin $\mathrm{D}_{3}$ in its active form, produced by the kidney in response to parathyroid hormone (Clark \& Simkiss, 1980 ), plays a critical role in the active uptake of $\mathrm{Ca}$ from the gut (Wasserman \& Taylor, 1969) (Fig. 3). Passive transport is independent of vitamin $\mathrm{D}_{3}$, and this mechanism seems to be the major one when levels of $\mathrm{Ca}$ in the diet are sufficiently high.

The absorption of $\mathrm{Ca}$ from the intestinal contents is limited in non-laying hens (Common, 1943; Hurwitz \& Griminger, I960; Taylor \& Kirkley, 1967) but with the onset of sexual reproduction the capacity to absorb $\mathrm{Ca}$ increases considerably. This change is brought about by the ovarian oestrogens (see Simkiss, I96r; Gilbert, 1967, 1969a; Dacke, 1979).

The total amount of $\mathrm{Ca}$ that can be absorbed will depend on several factors, the most obvious being the level of $\mathrm{Ca}$ in the diet, though the relationship between this and the amount absorbed is not a simple one (Wasserman \& Taylor, 1969; Simkiss, 1975). Hurwitz \& Bar (1969) suggested that no maximum absorptive rate was reached even on diets with concentrations of Ca greater than $40 \mathrm{~g} / \mathrm{kg}$ and it seems reasonable to accept that the intestine can transport at least up to about $2.5 \mathrm{~g} / \mathrm{d}$.

Consequently, with dietary concentrations of $\mathrm{Ca}$ up to approximately $25 \mathrm{~g} / \mathrm{kg}$ diet, it should be possible theoretically for $100 \%$ absorption to be achieved; however, in vivo this is never accomplished. Even with diets containing as little as $6 \mathrm{~g} \mathrm{Ca} / \mathrm{kg}$, uptake does not appear to exceed between 80 and $90 \%$ of that possible (Hurwitz \& Bar, 1969) (Fig. 4). Hence the relationship between the amount of $\mathrm{Ca}$ absorbed and its concentration in the intestinal contents is curvilinear (Fig. 4), with the percentage absorption falling to about $50 \%$ with the higher concentrations. However, the mechanisms for the uptake of $\mathrm{Ca}$ work in favour of the higher levels of dietary $\mathrm{Ca}$; for example, uptake of $\mathrm{Ca}$ from a diet containing approximately $40 \mathrm{~g} \mathrm{Ca} / \mathrm{kg}$ was found to be about $2.4 \mathrm{~g} / \mathrm{d}$ (Hurwitz \& Bar, 1969), more than sufficient for normal shell production, yet on a diet containing $17 \mathrm{~g}$ $\mathrm{Ca} / \mathrm{kg}$ the uptake was only $\mathrm{r} \cdot 3 \mathrm{~g} / \mathrm{d}$, in spite of the capacity of the intestine to 


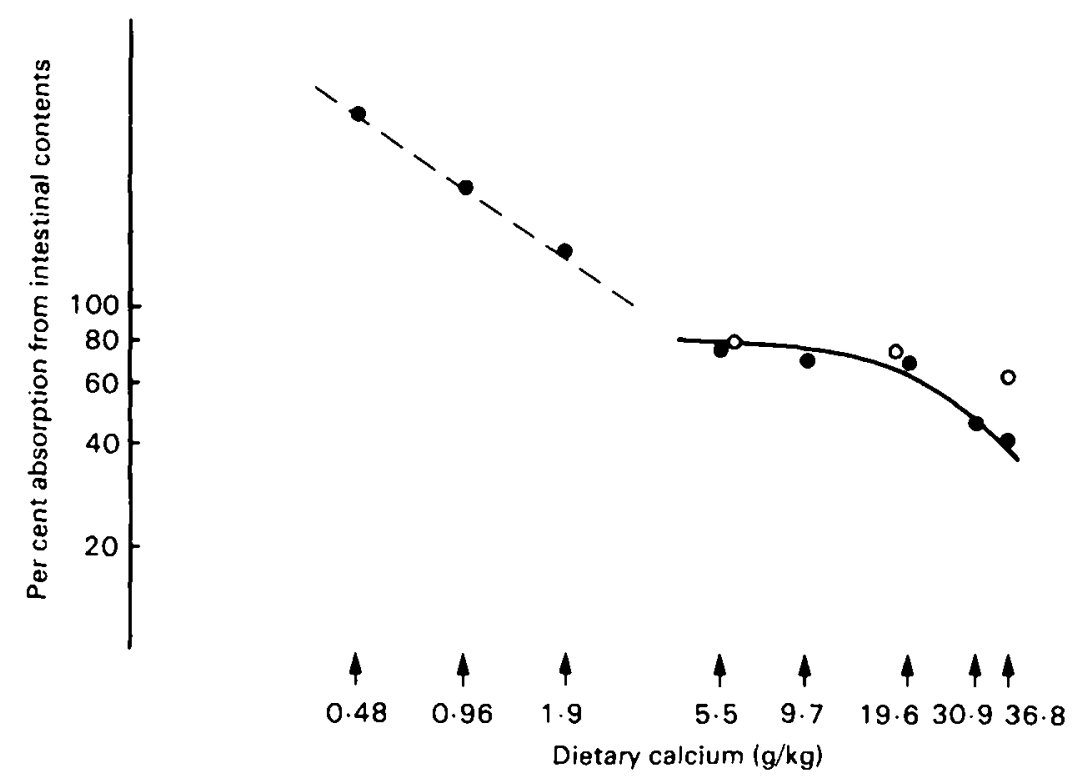

Fig. 4. From Fig. 7 (see p. 205) it is possible to calculate the minimum absorption possible for each dietary level of calcium if the birds are to remain in $\mathrm{Ca}$ balance (values above $100 \%$. Between 80 and $90 \%$ appears to be the maximum proportion of Ca that can be absorbed from the total $\mathrm{Ca}$ in the intestinal contents. This theoretical value agrees well with the actual measured intake reported by Hurwitz \& Bar ( 1969$)(0)$. (Double logarithmic plot.)

transport nearly twice as much. The reason is that most $\mathrm{Ca}$ is absorbed by a passive transport mechanism and, consequently, the major factor will be the amount of soluble Ca present in the intestinal contents (Mongin, I980). The fact that birds eat more on shell-forming days than on non-shell-forming days and that they have an extra period of eating in late afternoon, may account for the apparent greater absorptive capacity during the times when active shell formation is taking place (Hurwitz \& Bar, 1965, 1969; Bronsch et al. 1967; Itoh, 1967; Taylor \& Kirkley, 1967; Hurwitz et al. 1973; Bar \& Hurwitz, 1975; Bar et al. 1976; Hurwitz, 1976).

Ca reserves. It is clearly evident that if a hen does not produce a shell on any given day then her intake of $\mathrm{Ca}$ is likely to be in excess of her needs. Moreover, approximately 2 weeks before the commencement of laying the processes involved in providing large quantities of $\mathrm{Ca}$ for reproduction come into operation, despite the fact that there is no loss of $\mathrm{Ca}$ in the shell. Also, much of the daily intake of $\mathrm{Ca}$ occurs at a time when shelling is not taking place. This excess of $\mathrm{Ca}$ is not, in the main, excreted but it is placed in the specialized medullary bone developed in the cavities of the majority of the long bones (Simkiss, $196 \mathrm{I}$ ). The formation of this bone is controlled by the ovarian oestrogens and androgens (Gilbert, 1967; Dacke, 1979) though deposition of $\mathrm{Ca}$ and its withdrawal are regulated specifically by calcitonin and parathyroid hormone respectively (Dacke, 1979); vitamin $\mathrm{D}_{3}$ may also be involved (Dacke, 1979) (see Fig. 3). 
Medullary bone is a very labile type of bone (Hurwitz, 1965; Simkiss, 1967) and it has been generally held that this is used specifically to store $\mathrm{Ca}$ for use in reproduction (Petersen, 1965; Simkiss, 1967; Clark \& Simkiss, 1980; Taylor, I970a, 1980; Speers, 1970) thus acting as a buffer when dietary supplies of Ca are insufficient. However, this view has been questioned by Simkiss (1975). The active medullary bone contains sufficient $\mathrm{Ca}$ for only two to six eggs (Petersen, 1965; Simkiss, 1967 ; Speers, 1970) so that its role as a storage organ is limited. What is more, medullary bone remains constant during $\mathrm{Ca}$ deprivation while the amount of cortical bone decreases (Taylor \& Moore, 1954; Simkiss, 1967). Hence, rather than a store, it seems more likely that the function of the medullary bone is to provide a source of readily available $\mathrm{Ca}$ for the regulation of plasma levels during shell calcification and for which cortical bone is not so suitable (Taylor, 1970a; Simkiss, 1967,1975 ; Speers, 1970). If this is so, clearly the use of cortical bone in this way could not continue for long without severe repercussions (Morris \& Nalbandov, 1958; Bell \& Siller, 1962). For this reason, the hen cannot be regarded as having a major reserve store of $\mathrm{Ca}$.

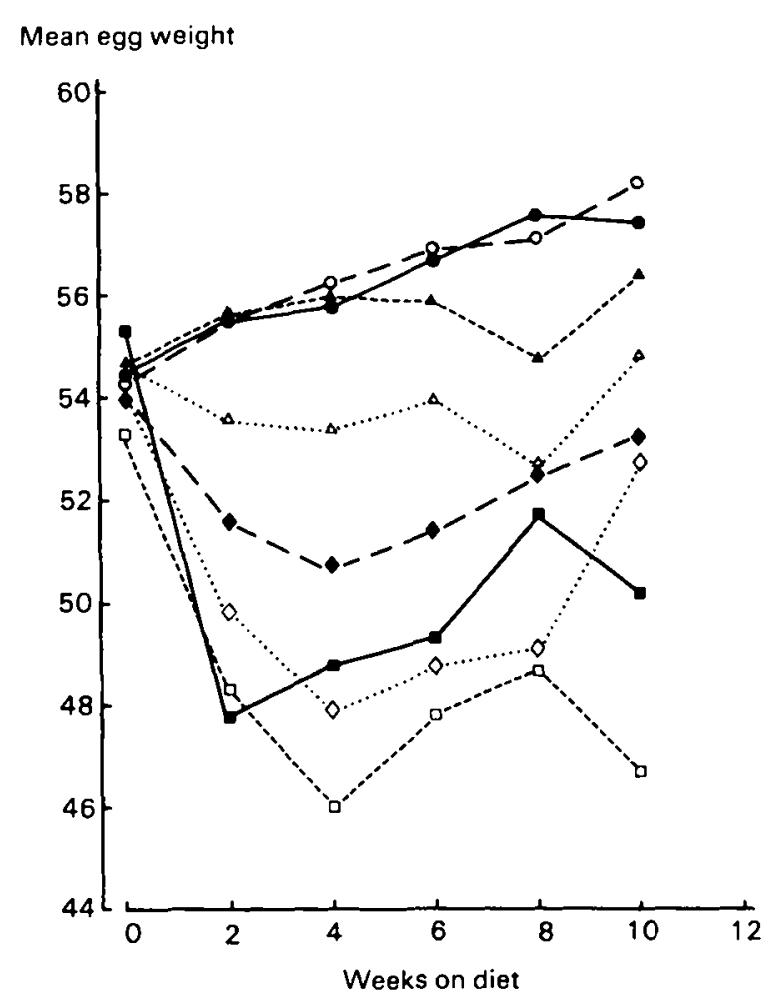

Fig. 5. Mean egg weight in relation to the calcium content of the diet. The tendency for egg weight to increase with age (birds on dietary $\mathrm{Ca}$ of 36.8 and $30.9 \mathrm{~g} / \mathrm{kg}$ ) is typical of domestic fowl generally. In all other groups this tendency can still be seen after the initial decrease in

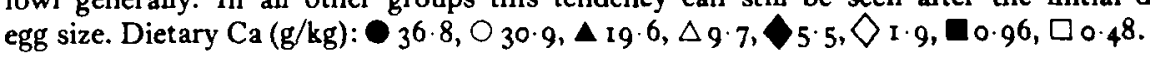




\section{Ca output and egg production}

Urinary $\mathrm{Ca}$. The excretion of $\mathrm{Ca}$ through the kidney is governed almost entirely by the reabsorptive capacity of the kidney tubule and, under normal conditions, ${ }^{8} 8-99 \%$ of the filtered $\mathrm{Ca}$ is reabsorbed; this reabsorption is under direct control of the parathyroid (Dacke, 1979; Clark \& Simkiss, 1980) (Fig. 3). Consequently, even when hens are fed on diets containing large quantities of $\mathrm{Ca}$, urinary excretion of $\mathrm{Ca}$ is low, between approximately $40 \mathrm{mg}$ and $200 \mathrm{mg} / \mathrm{d}$ on shell-forming days (Fussell, 1960; Taylor \& Kirkley, 1967; Hurwitz \& Bar, 1969). Since excretion rises on non-shell-forming days (Fussell, 1960; Taylor \& Kirkley, 1967), it seems likely that the kidney is working at maximum efficiency in the retention of $\mathrm{Ca}$ on days when an egg is being formed. For this reason further reductions in the loss of $\mathrm{Ca}$ by these means seems unlikely to be achieved.

Shell $\mathrm{Ca}$. Shell $\mathrm{Ca}$ would seem likely to be affected when the supply of Ca varies and there is a considerable body of industrial and experimental experience which supports this view (Urist, 1959; Hurwitz \& Griminger, 1960; Petersen et al. 1960; Helbacka, 1961; Combs, 1962; MacIntyre et al. 1963; Sanford, 1964). With dietary levels of between 25 and $80 \mathrm{~g} \mathrm{Ca} / \mathrm{kg}$, shell thickness was found to be proportionally related to the amount of $\mathrm{Ca}$ in the diet. This work has been extended (Gilbert et al. $198 \mathrm{I}$ ) with diets ranging from approximately 0.5 to $35 \mathrm{~g}$ $\mathrm{Ca} / \mathrm{kg}$ with similar results. Total shell weight ranged between $2.55 \mathrm{~g}$ for the

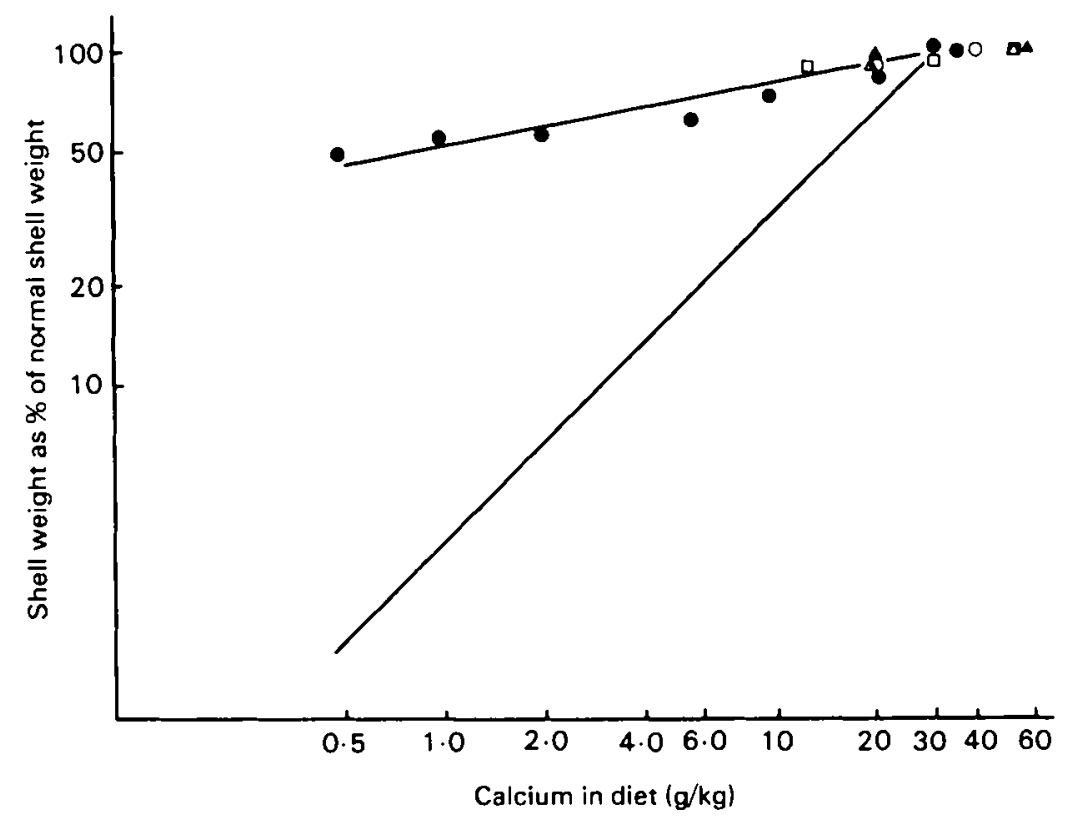

Fig. 6. Shell weight as a percentage of normal shell weight in relation to the calcium content of the diet (double logarithmic plot). The lower line is the $45^{\circ}$ line. Results taken from Gilbert et al.

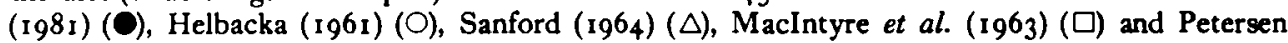
et al. $(\mathrm{I} 960)(\mathbf{A})$. 
smaller concentrations to $5.3 \mathrm{I} \mathrm{g}$ for the larger ones. Part of the difference was accounted for by a reduction in egg size on the diets with less $\mathrm{Ca}$ (Fig. 5) and part by a reduction in shell thickness (Fig. 6). However, though the quantity of shell produced varies with the amount of $\mathrm{Ca}$ available, the actual variation in shell output is small in comparison to the variation in dietary intake (Fig. 6). For example, with a diet containing $20 \mathrm{~g} \mathrm{Ca} / \mathrm{kg}$ the average shell deposited on each egg remained for about 8 weeks at $92 \%$ of that which was deposited with a $35 \mathrm{~g} \mathrm{Ca} / \mathrm{kg}$ diet, even though dietary intake was reduced to less than $60 \%$ of the higher level. The situation is more remarkable for the diet containing the least $\mathrm{Ca}(0.5 \mathrm{~g} / \mathrm{kg})$; with this diet shell production was maintained for a similar length of time at about $50 \%$ of normal, whereas daily intake of $\mathrm{Ca}$ was reduced to just above $1 \%$ of the normal.

Ovarian function and oocyte production. It has been recognized for some time that low concentrations of dietary $\mathrm{Ca}$ have an adverse effect on egg production (Evans et al. 1944; Hurwitz \& Griminger, I960; Sullivan \& Kingan, 1962). Taylor $(1965,1970 b, 1972)$ argued that pituitary function was related to the amount of $\mathrm{Ca}$ available and when $\mathrm{Ca}$ supply is low a protective mechanism operates to prevent ovulation. Thus, the amount of $\mathrm{Ca}$ in the diet was argued to be an important regulatory factor in ovarian function.

In contrast to this view, Gilbert ( 1967 ) first drew attention to the fact that there appeared to be a relationship between shell formation (rather than the supply of $\mathrm{Ca}$ ) and ovarian function. It seemed from the evidence that ovarian function was used to regulate the loss of $\mathrm{Ca}$ and this concept was further developed by Gilbert (1969a, 1971d) and by Gilbert \& Wood-Gush (1971). Hens induced to lay soft-shelled eggs on a high level of dietary $\mathrm{Ca}$ (approximately $35 \mathrm{~g} / \mathrm{kg}$ diet) had higher ovulation rates than did normal hens on similar diets (Lake \& Gilbert, 1964). Also Wood-Gush \& Gilbert (1965), using nesting as a method to study ovulation in hens with ligated oviducts, found similar results. The consistent feature of this work was that enhancement of ovulation rate appeared to be associated with a reduction in the loss of $\mathrm{Ca}$ when normal shell production was prevented (Gilbert \& Wood-Gush, 1968). Thus, when dietary intake remains high, ovulation rate (egg number) apparently varies inversely with $\mathrm{Ca}$ output in the shell.

However, when dietary intake is low, the amount of shell that is produced decreases. Nevertheless, shell calcification does not fall in direct proportion to the amount of $\mathrm{Ca}$ in the diet. Consequently, if similar mechanisms were operating at the lower concentrations of dietary $\mathrm{Ca}$ as at the higher ones, then egg production would be expected to be approximately proportional to the available $\mathrm{Ca}$ in the diet. Until recently, there was no conclusive evidence that this was so. Hurwitz \& Griminger ( 1960$)$, MacIntyre et al. (1963), Mehring (1965) and Arends et al. ( 1967 ) did report reduced egg production with lowered $\mathrm{Ca}$ intake but the work of, for example, Petersen et al. (1960), Helbacka (1961), Combs (1962), Macintyre et al. $(1963)$ and Sanford ( 1964$)$, did not appear entirely to agree. In contrast, Morris \& Nalbandov (1958) reported a complete cessation of laying with exceptionally low levels of dietary $\mathrm{Ca}$. 
Recently a re-examination of the egg-laying of hens in response to varying the dietary intake of $\mathrm{Ca}$ was carried out by Gilbert et al. (I98I) using eight diets containing amounts of $\mathrm{Ca}(\mathrm{g} / \mathrm{kg})$ ranging from 0.48 to 36.8 . With all but the two diets with the highest levels of $\mathrm{Ca}(36.8$ and $30.9 \mathrm{~g} / \mathrm{kg}$ respectively), egg production fell rapidly when the diets were fed: thereafter, egg production continued to fall for several weeks until the rate of production levelled out. Moreover, not only the initial rate of decline but also the final minimum rate of lay appeared to depend on the actual amount of $\mathrm{Ca}$ in the diet. For example, the group of hens on diet $3(19.6 \mathrm{~g} \mathrm{Ca} / \mathrm{kg})$ had a slower rate of decline and a higher final level of production than did the group of hens on diet $4(9.7 \mathrm{~g} \mathrm{Ca} / \mathrm{kg})$, and so on. The final level of production for hens on the extremes of dietary $\mathrm{Ca}(36.8$ and $0.48 \mathrm{~g}$ $\mathrm{Ca} / \mathrm{kg}$ ) were 93 and $5 \%$ respectively. Thus, even on the lowest level used, egg production still took place, albeit at a very low rate (i.e. one egg about every $20 \mathrm{~d}$ ). This is in contrast to earlier views that extremely low dietary intakes of $\mathrm{Ca}$ will prevent egg production; moreover, this observation is consistent with the earlier reports that hens on diets containing approximately $0.5 \mathrm{~g} \mathrm{Ca} / \mathrm{kg}$ had functional ovaries and oviducts, and had the external appearance of being in lay (Douglas et al. 1972; Gilbert \& Blair, 1975). For the five diets with amounts of Ca between $\mathrm{I} .9$ and $30.9 \mathrm{~g} / \mathrm{kg}$, egg production was almost directly proportional to the amount of $\mathrm{Ca}$ in the diet (Fig. 7). Only on the two diets with the lowest amounts of $\mathrm{Ca}$ $\left(0.4^{8}\right.$ and $\left.0.96 \mathrm{~g} / \mathrm{kg}\right)$ was egg production much higher than expected by direct proportionality.

It is interesting that with all diets containing less than $30.9 \mathrm{~g} \mathrm{Ca} / \mathrm{kg}$, egg production was higher than would have been expected for complete conservation

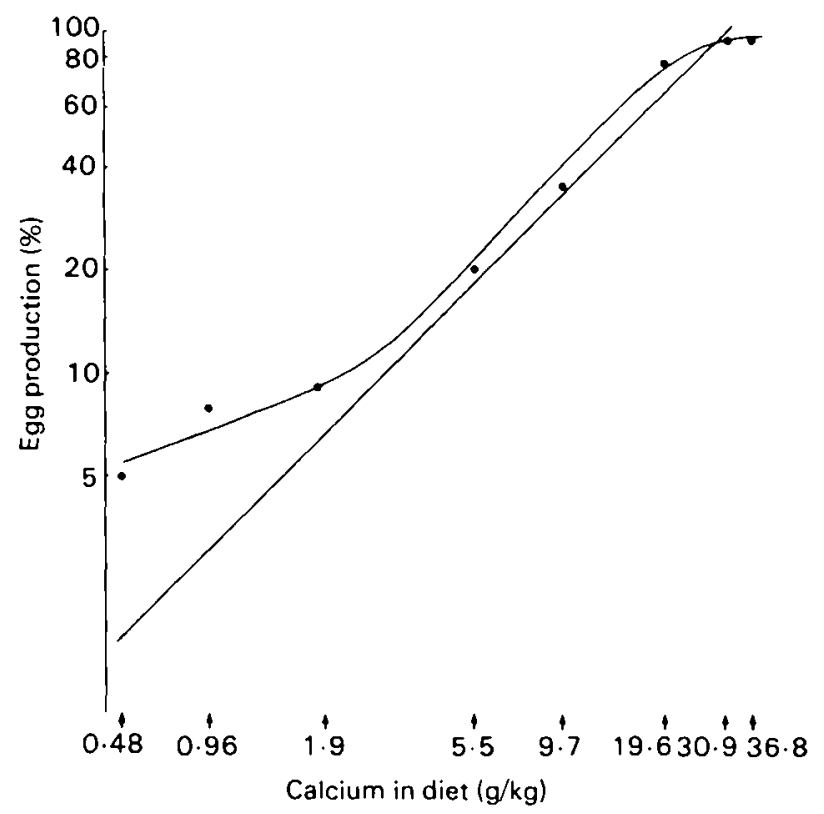

Fig. 7. Percentage egg production in relation to calcium content of the diet (double logarithmic plot). The straight line is the $45^{\circ}$ line. 


\section{Calcium}

input or output

(g)

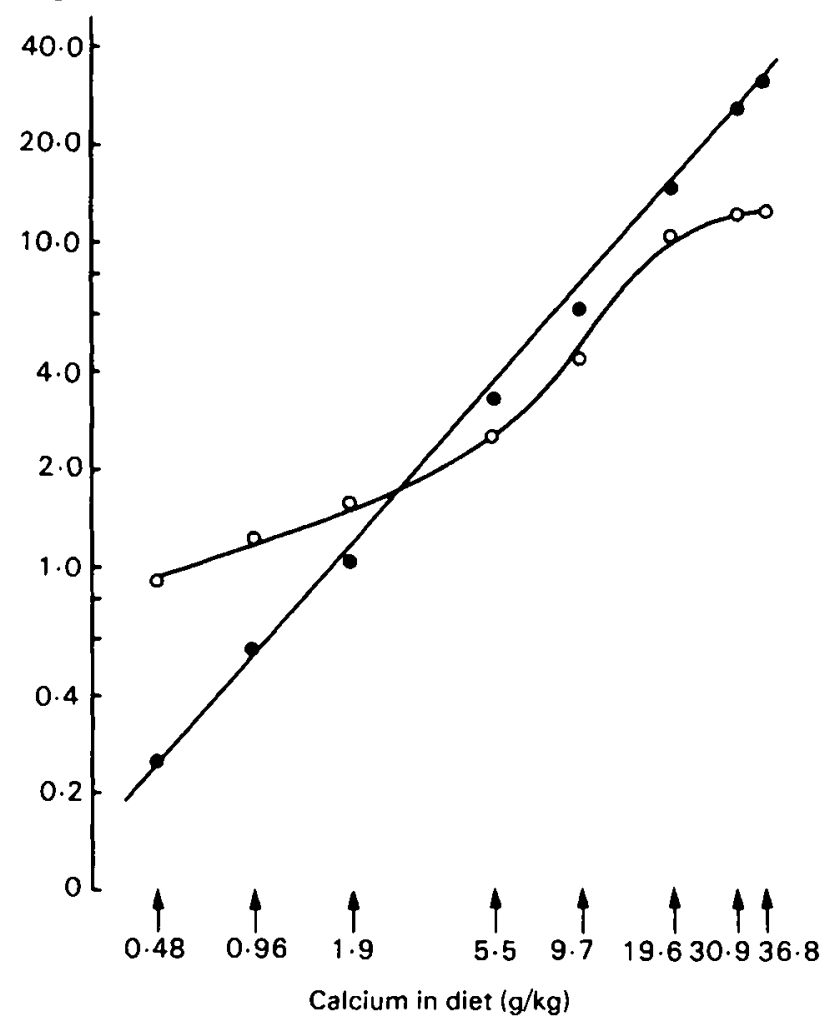

Fig. 8. Calcium input (O) and $\mathrm{Ca}$ output in the egg $(O)$ plotted against the $\mathrm{Ca}$ content of the diet. (Results from Gilbert et al. $198 \mathrm{r}$.)

of Ca. However, as shell calcification was less on all these diets except those with the lowest $\mathrm{Ca}$ concentrations $\left(0.4^{8}\right.$ and $\left.0.9 \mathrm{~g} / \mathrm{kg}\right)$, hens were in positive $\mathrm{Ca}$ balance (Fig. 8). Even on the two lowest diets, only between 7 and $8 \mathrm{~g}$ more Ca was lost during the II weeks of the experiment than could be obtained from the diet, an amount usually regarded as being within the capabilities of the hen to supply without undue detriment. This work suggests that in the first instance the supply of $\mathrm{Ca}$ is not per se a regulator of ovarian function. What appears to be important is the regulation of ovarian function to control the loss of $\mathrm{Ca}$ in the shell to that which is available from the diet. Other evidence supports this view. Immature hens placed on a diet with $0.5 \mathrm{~g} \mathrm{Ca} / \mathrm{kg}$ diet came into lay and produced three or so eggs in a normal way (Gilbert, 1973) before the effect of the restricted intake of $\mathrm{Ca}$ led to a reduced egg production at a very low level. If the amount of $\mathrm{Ca}$ in the diet has a direct effect on the ovary or the mechanisms controlling it, this would not have been expected to occur. The other evidence concerns a group of hens made into obligatory shell-less layers and two groups of normal hens. When one of the normal groups of hens was placed on a low-Ca diet $(0.5 \mathrm{~g} / \mathrm{kg})$ egg production rapidly fell to 


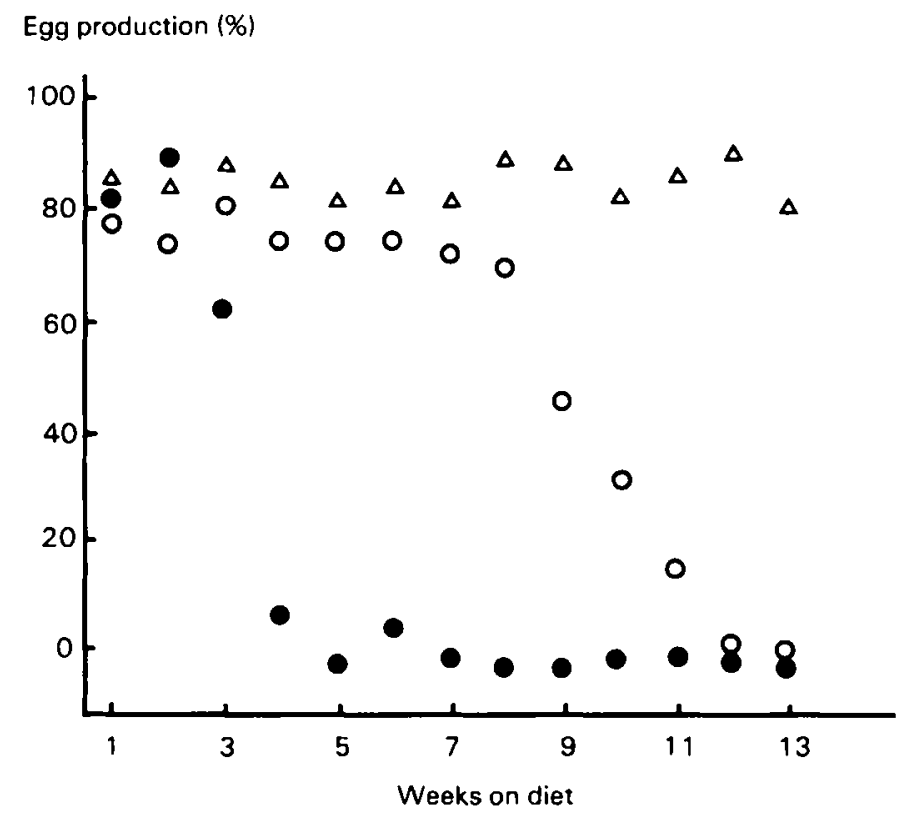

Fig. 9. Mean weekly rate of lay for normal birds $(\Delta)$, and normal birds $(O)$ and birds laying obligatory soft shelled eggs $(O)$ given a diet containing $0.3 \mathrm{~g} \mathrm{Ca} / \mathrm{kg}$. (Results from Gilbert, $1969 b$.)

negligible levels, but with the shell-less layers egg production was maintained at a level similar to the other control group on a normal $35 \mathrm{~g} \mathrm{Ca} / \mathrm{kg}$ diet (Gilbert, 1969b) (Fig. 9). Thus, the amount of $\mathrm{Ca}$ in the diet did not by itself appear to be related directly to egg production. Interestingly, because some $\mathrm{Ca}$ was being lost in the egg of the shell-less layers they reacted normally after about 6 weeks when egg production was reduced to that of the normal hens on the low-Ca diet.

\section{Calcium balance}

Reproduction involving the formation of an egg with a heavily calcified shell could lead to a dangerous condition unless mechanisms are available either to provide sufficient $\mathrm{Ca}$ at all times or to reduce $\mathrm{Ca}$ loss when the supply of $\mathrm{Ca}$ is reduced. Although modern husbandry practices have reduced the risks, it is clear that the hen has some inherent mechanisms available to her.

Of these two options, the provision of adequate amounts of $\mathrm{Ca}$ at all times does not seem to be attainable. Variation in food intake appears to be associated mainly with the daily fluctuations in $\mathrm{Ca}$ requirements concomitant with actual shell formation if a shell is being formed rather than to regulate a positive $\mathrm{Ca}$ balance. Moreover, laying hens tend to find diets containing small quantities of $\mathrm{Ca}$ distasteful, and this may be a mechanism to encourage them to seek more suitable alternative diets. 
Similarly, it is also evident that regulation of $\mathrm{Ca}$ absorption is not a mechanism that the hen is able to use to any extent to maintain an optimal level of $\mathrm{Ca}$ input; if this were so, it would be expected that as the concentration of dietary Ca falls, the amount of $\mathrm{Ca}$ absorbed would rise in compensation. Instead the opposite appears to be true and a consideration of the relative proportion of $\mathrm{Ca}$ absorbed from the intestinal contents is misleading. What is more, the hen does not have a true reserve of $\mathrm{Ca}$ on which she can call at times when the $\mathrm{Ca}$ supply is unfavourable.

Clearly none of these mechanisms is able to maintain a proper balance under all conditions, particularly with diets containing small amounts of $\mathrm{Ca}$. Indeed, the major factor in the supply of $\mathrm{Ca}$ to the hen appears to be the quantity of $\mathrm{Ca}$ in the diet and, for the most part, the hen has little control over this except by seeking diets richer in $\mathrm{Ca}$ than are immediately available. This being so, the maintenance of a positive $\mathrm{Ca}$ balance seems to depend almost entirely on the control of $\mathrm{Ca}$ output. In this respect it is significant that the amount of $\mathrm{Ca}$ ingested is unimportant by itself because, if the output of $\mathrm{Ca}$ is reduced by artificial means to negligible amounts, all the normal physiological processes associated with reproduction will continue even on diets containing as little as $0.5 \mathrm{~g} \mathrm{Ca} / \mathrm{kg}$.

In the control of $\mathrm{Ca}$ output, further reduction of $\mathrm{Ca}$ in the urine can have little effect, except in very marginal conditions, because the output in urine is normally very low. Consequently, the major control mechanisms can only operate through varying the amount of shell produced on each egg and through varying the number of eggs produced.

The first response to a reduced $\mathrm{Ca}$ intake is an immediate reduction in the amount of shell which is deposited on each egg. Despite this, the reduction in shell is not sufficient to compensate entirely for the reduction in the available $\mathrm{Ca}$ in the diet. Consequently, within a short time there is a marked decrease in the number of eggs produced and this decline continues for several weeks until a production level is reached which is proportional to the available $\mathrm{Ca}$ in the diet.

It is interesting that the first response to a reduced dietary intake of $\mathrm{Ca}$ appears in the shell and only later is egg production affected. However, each shell is produced within a single $24 \mathrm{~h}$ period whereas the full growth of an oocyte takes upwards of a week (Gilbert, 1971 c, 1972). For this reason, it is possible for the reduction of shell output to be effective in conserving $\mathrm{Ca}$ within $24 \mathrm{~h}$ while changes in egg production are not likely to be able to operate for at least several days.

During the interim period when egg production is still falling, a negative balance exists and presumably during this time hens must be drawing $\mathrm{Ca}$ from the bone (Fig. I0). Moreover, not all birds are equally efficient in regulating their $\mathrm{Ca}$ loss and Gilbert et al. (1981) reported several instances of leg weakness, particularly with the middle range of dietary $\mathrm{Ca}$. Also, the so-called 'cage layer fatigue' syndrome (Bell \& Siller, I962) is not unknown in commercial flocks, even today, and Taylor \& Moore (1954) reported that some birds lost up to $40 \%$ of their total body $\mathrm{Ca}$, with obvious consequences. Perhaps the requirement for higher production rates in modern laying strains has tended to reduce the effectiveness of the natural protective mechanisms (Taylor et al. 1962; Gilbert et al. 198I). It is 


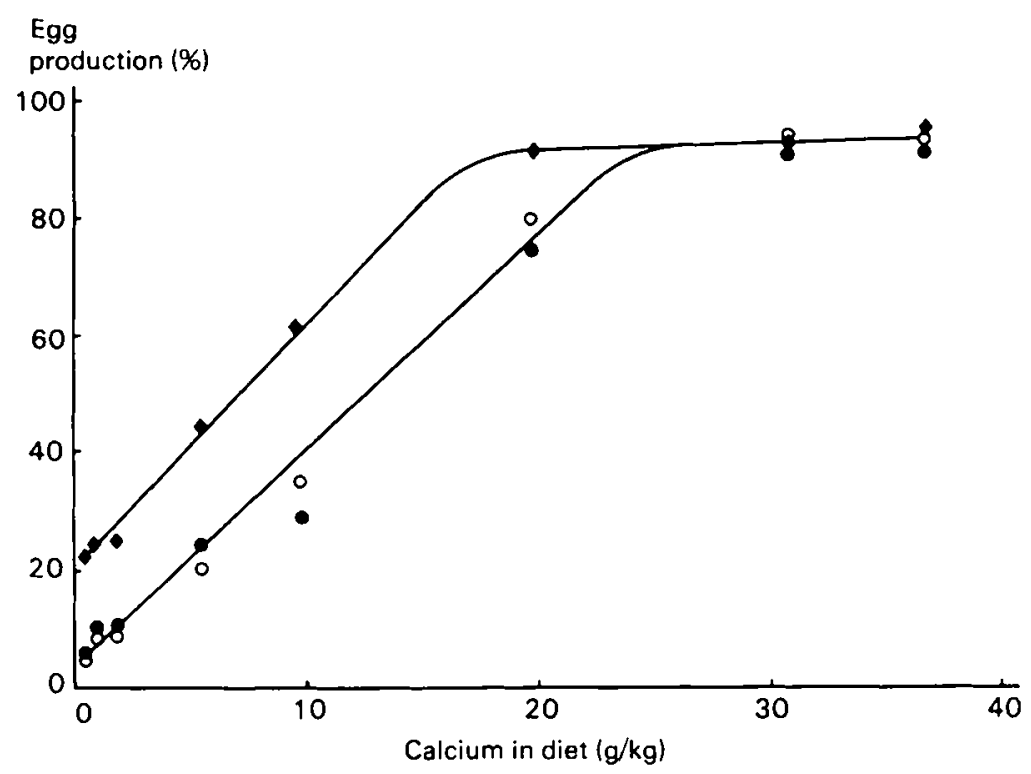

Fig. 10. Egg production plotted against dietary calcium. Birds during the first 3 weeks after feeding the diet $(\triangle)$, birds during the $4^{\text {th }}$ to $7^{\text {th }}$ week $(O)$ and birds during the 8 th to roth week (O). (Results from Gilbert et al. 1981.)

certainly an aspect which breeders should consider in planning future selection programmes.

Regulation of $\mathrm{Ca}$ balance by controlling the number of eggs produced may seem a clumsy mechanism when most of the $\mathrm{Ca}$ that is lost is contained in the shell and a more reasonable supposition would seem to be for shell output to be regulated directly. However, an egg is the mechanism by which a viable offspring is produced. For this reason the egg must provide a suitable medium for embryological growth and development, and the shell has important functions to perform. Hence, if the shell were to be reduced below a critical level, it is unlikely that survival of the developing chick could occur and, no matter how many such eggs as these were produced, the chances of reproduction taking place would be minimal. In contrast, the production of even a few relatively normal eggs would provide a much better chance for reproduction to be successfully accomplished. Thus, the production of normal eggs consistent with the available Ca appears to satisfy both biological axioms 'the survival of the individual' and 'the survival of the species'.

There is no doubt that the number of eggs produced by the domestic hen is related to her need to maintain a positive $\mathrm{Ca}$ balance. If she can be regarded as having mechanisms typical of birds generally, and turkeys also seem to be similar (Arends et al. 1967; Atkinson et al. 1967), then possibly many wild birds may regulate their reproduction in the same way. It is often expressed that poor egg production in wild birds is a feature distinguishing them from the chicken. 
However, several instances of extremely high production rates have been reported in wild birds when conditions were suitable (Welty, 1962; Clayton, 1972) and it would be of interest to consider whether the normally restricted laying of wild birds (Davis, I955) is in any way related to the availability of $\mathrm{Ca}$ in their respective diets.

Because $\mathrm{Ca}$ intake by itself is not important and because egg production will continue at very low levels of intake if output in the shell is restricted, it has been suggested that the hen has a mechanism by which she can determine her output loss in relation to her dietary input (Gilbert, $1969 b$ ). The mechanisms involved in monitoring such a relationship are not known. The pituitary gonadotrophins seem to be involved and hens placed on a low-Ca diet $(2 \mathrm{~g} / \mathrm{kg})$ can be induced to continue laying by administering follicle stimulating hormone (Morris \& Nalbandov, I958; Taylor et al. 1962 ). Luck \& Scanes (1980) suggested that there may be a direct effect of circulating $\mathrm{Ca}$ on the pituitary, though their earlier work (Luck \& Scanes, I979) indicated a hypothalamic malfunction on low-Ca diets therefore supporting the suggestion (Taylor, 1965, 1970a; Simkiss, 1967) that the hypothalamus is involved in restricting severe losses of $\mathrm{Ca}$. Circulating levels of $\mathrm{Ca}$, particularly of ionic $\mathrm{Ca}$, are likely to be important (Luck \& Scanes, 1979), though there is little information available. Moreover, the situation is complicated by cyclical daily variations in plasma $\mathrm{Ca}$ associated directly with shell formation (Parsons \& Combs, I98I) and the fact that much of the plasma $\mathrm{Ca}$ is bound to the yolk proteins. Similarly there is, as yet, insufficient evidence to consider the interaction between $\mathrm{Ca}$ and the hormonal control of ovarian function or the mechanisms which determine how many oocytes develop. The influence of ovarian function on $\mathrm{Ca}$ metabolism may be a further field worthy of study, particularly since the eating of calcareous grit independently of food (Hughes, 1972) and the activation of 1,25 -hydroxy vitamin $\mathrm{D}_{3}$ by the kidney (Kenny, 1975) both appear to be related to ovulation and not to shell calcification per se.

By trying to approach the subject of $\mathrm{Ca}$ metabolism from this viewpoint, I hope to have stimulated new interest in this most intriguing subject, not only in domestic birds, but also in wild birds where there are many profitable fields of study which could throw new light on the role of $\mathrm{Ca}$ in avian reproduction.

\section{REFERENCES}

Arends, L. G., Miller, D. L. \& Balloun, S. L. (1967). Poult. Sci. 46,727.

Atkinson, R. L., Bradley, J. W., Crouch, J. R. \& Quisenberry, L. H. (1967). Poult. Sci. 46, 207.

Bar, A., Eisner, U., Montecuccoli, G. \& Hurwitz, S. (1976). F. Nutr. 1o6, 1 336.

Bar, A. \& Hurwitz, S. (1975). Poult. Sci. 54, I 325.

Bell, D. J. \& Siller, W. G. (1962). Res. vet. Sci. 3, 219.

Berg, L. R., Bearse, G. E. \& Merrill, L. H. (I964). Poult. Sci. 43, 885 .

Bronsch, K., Lorcher, K. \& Stadler, B. (1967). Z. Veterinarmed. 14, 105.

Clark, N. B. \& Simkiss, K. (1980). In Avian Endocrinology, p. I 9 I [A. Epple and M. H. Stetson, editors]. London and New York: Academic Press.

Clayton, G. A. (1972). F. reprod. Fert. Suppl. 15, I.

Combs, G. F. (1962). Maryland Nutrition Conference for Feed Manufacturers, p. 65.

Common, R. H. (1943). F. agric. Sci., Camb. 33, 213. 
Dacke, C. G. (1979). Calcium Regulation in Sub-mammalian Vertebrates. London and New York: Academic Press.

Damron, B. L. \& Harms, R. H. (1980). Poult. Sci. 59, 82.

Davidson, J. \& Boyne, A. W. (1970). Br. Poult. Sci. I1, 23 I.

Davis, D. E. (1955). In Research Studies in Avian Biology, p. 264 [A. Wolfson, editor]. Urbana: University of Illinois Press.

Douglas, C. R., Harms, R. H. \& Wilson, H. R. (1972). Poult. Sci. 51, 2015.

Duncan, I. J. H., Horne, A. R., Hughes, B. O. \& Wood-Gush, D. G. M. (1 970). Anim. Behav. $18,245$.

Evans, R. J., Carew, J. S. \& Brant, A. W. (1944). Poult. Sci. 23, 36.

Fussell, M. H. (1960). Studies on calcium and phosphorus metabolism in the hen. PhD Thesis, University of Cambridge.

Gilbert, A. B. (1967). In Advances in Reproductive Physiology, p. I I [Anne McLaren, editor]. London: Logos Press.

Gilbert, A. B. (1969a). Wld's Poult. Sci. F. 25, 239.

Gilbert, A. B. (1969b). Br. Poult. Sci. 10, 83 .

Gilbert, A. B. (1971 a). In Physiology and Biochemistry of the Domestic Fowl, p. I 153 [D. J. Bell and B. M. Freeman, editors]. London and New York: Academic Press.

Gilbert, A. B. (1971 b). In Physiology and Biochemistry of the Domestic Fowl, p. 1379 [D. J. Bell and B. M. Freeman, editors]. London and New York: Academic Press.

Gilbert, A. B. (197IC). In Physiology and Biochemistry of the Domestic Fowl, p. I 163 [D. J. Bell and B. M. Freeman, editors]. London and New York: Academic Press.

Gilbert, A. B. (I971d). Proc. I4th Wld's Poult. Congr., Madrid, p. $78 \mathrm{I}$.

Gilbert, A. B. (1972). In Egg Formation and Production, p. 3 [B. M. Freeman and P. E. Lake, editors]. Edinburgh: British Poultry Science Ltd.

Gilbert, A. B. (1973). 4th Europ. Poult. Conf., London, p. 69.

Gilbert, A. B. (1979). In Form and Function in Birds, p. 237 [A. S. King and J. McLelland, editors]. London and New York: Academic Press.

Gilbert, A. B. \& Blair, R. (1975). Br. Poult. Sci. 16, 547.

Gilbert, A. B., Peddie, J., Mitchell, G. G. \& Teague, P. W. (1981). Br. Poult. Sci. 22, 537.

Gilbert, A. B. \& Wood-Gush, D. G. M. (1968). Br. Poult. Sci. 9, 26 r.

Gilbert, A. B. \& Wood-Gush, D. G. M. (1971). In Physiology and Biochemistry of the Domestic Fowl, p. 1353 [D. J. Bell and B. M. Freeman, editors]. London and New York: Academic Press.

Helbacka, N. V. (196I). Maryland Nutrition Conference for Feed Manufacturers, p. 46.

Hughes, B. O. (1972). Br. Poult. Sci. 13, 485.

Hughes, B. O. \& Wood-Gush, D. G. M. (1971). Anim. Behav. 19, 490.

Hull, S. J. \& Scott, M. L. (1969). Proc. Cornell Nutr. Conf., p. 62.

Hurwitz, S. (1965). Am. F. Physiol. 73, 177.

Hurwitz, S. (1976). In Digestion in the Fowl, p. 157 [K. N. Boorman and B. M. Freeman, editors]. Edinburgh: British Poultry Science Ltd.

Hurwitz, S. \& Bar, A. (1965). F. Nutr. 86, 433.

Hurwitz, S. \& Bar, A. (1969). Am. F. clin. Nutr. 22, 39 I.

Hurwitz, S., Bar, A. \& Cohen, I. (1973). Am. F. Physiol. 225, 150.

Hurwitz, S., Bornstein, S. \& Bar, A. (1969). Poult. Sci. 48, 1453.

Hurwitz, S. \& Griminger, P. (1960). J. Agric. Sci. 54, 373.

Itoh, H. (I 967). Fap. F. zootech. Sc. $\mathbf{3}^{8}, 470$.

Kenny, A. D. (I 975). In Calcium-Regulating Hormones, p. 408 [R. V. Talmage, M. Owen and J. A. Parsons, editors]. Amsterdam: Excerpta Medica.

Lake, P. E. \& Gilbert, A. B. (1964). Res, vet. Sci. 5, 39.

Luck, M. R. \& Scanes, C. G. (1979). Br. Poult. Sci. 20, 559.

Luck, M. R. \& Scanes, C. G. (1980). Gen. Comp. Endocr. 41, 260.

MacIntyre, T. M., Chancey, H. W. R. \& Gardiner, E. E. (1963). Can. F. Anim. Sci. 43, 337.

Mehring, A. L. (1965). Poult. Sci. 44, 240.

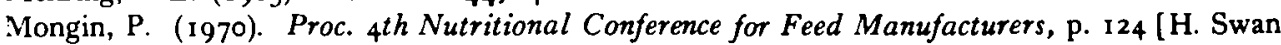
and D. Lewis, editors]. London: Churchill.

Mongin, P. (1980). Reprod. Nutr. Dev. 20, 155. 
Mongin, P. \& Sauveur, B. (1974). Br. Poult. Sci. 15, 349.

Morris, B. A. \& Taylor, T. G. (1967). Br. Poult. Sci. 8, 251.

Morris, T. R. \& Nalbandov, A. V. (1958). Endocrinology 68, 687.

Parsons, A. H. \& Combs, G. F. (1981). Poult. Sci. 60, 1520.

Petersen, C. F. (1965). Wld's Poult. Sci. F. 21, 110.

Petersen, C. F., Conrad, D. H., Lumijarvi, D. H., Sauter, E. A. \& Lampman, C. E. (1960). Idaho Agricultural Experimental Station Research Bulletin, no. 44.

Poultry Working Group no. 2 (Nutrition) (1981). Wld's Poult. Sci. $\mathfrak{f} .37,127$.

Roland, D. A., Sloan, D. R. \& Harms, R. H. (1972). Poult. Sci. 51 , 1388.

Romanoff, A. L. \& Romanoff, A. J. (1949). The Avian Egg. New York: John Wiley \& Sons.

Sanford, P. E. (1964). r 9 th Kansas Formula Feed Conference, p. 2.

Savory, C. J. (1979). In Food Intake Regulation in Poultry, p. 277 [K. N. Boorman and B. M. Freeman, editors]. Edinburgh: British Poultry Science Ltd.

Savory, C. J. (1980). Applied Anim. Ethology 6, 71.

Simkiss, K. (1961). Biol. Rev. 36, 321.

Simkiss, K. ( 1967$)$. Calcium in Reproductive Physiology. London: Chapman and Hall.

Simkiss, K. (1975). Symp. zool. Soc., Lond. 35, 307.

Simkiss, K. \& Taylor, T. G. (1971). In Physiology and Biochemistry of the Domestic Fowl, p. 133I [D. J. Bell and B. M. Freeman, editors]. London and New York: Academic Press.

Speers, G. M. (1970). Proc. $3_{1}$ st Ann. Minnesota Nutrition Conference, p. 127.

Sullivan, T. M. \& Kingan, J. R. (r 962). Poult. Sci. 4r, 1596.

Taylor, T. G. (1965). Proc. Nutr. Soc. $24,49$.

Taylor, T. G. (1970a). Ann. Biol. anim. Bioch. Biophys. 10, 83.

Taylor, T. G. (1970b). Proc. 4th Nutritional Conference for Feed Manufacturers, p. 108 [H. Swan and D. Lewis, editors]. London: Churchill.

Taylor, T. G. (1972). In Egg Formation and Production, p. 107 [B. M. Freeman and P. E. Lake, editors]. Edinburgh: British Poultry Science Ltd.

Taylor, T. G. (1980). 28th International Congress of Physiological Sciences, p. 3 II [G. Pethes, P. Peczely and P. Rudas, editors]. London: Pergamon Press.

Taylor, T. G. \& Kirkley, J. (1967). Br. Poult. Sci. 8, 289.

Taylor, T. G. \& Moore, J. H. (1954). Br. F. Nutr. 8, I I 2.

Taylor, T. G. \& Moore, J. H. (1956). Br. $\mathscr{~}$. Nutr. 10, 250.

Taylor, T. G., Morris, T. R. \& Hertelendy, F. (1962). Vet. Rec. 74, 123.

Taylor, T. G. \& Stringer, D. A. (I965). In Avian Physiology, p. 485 [P. D. Sturkie, editor]. Ithaca: Cornell University Press.

Tyler, C. \& Wilcox, J. S. (1942). f. Agr. Sci. 32, 43.

Urist, M. R. (1959). Recent Prog. Horm. Res. $15,455$.

Wasserman, R. H., Corrinadino, R. A., Fullmer, C. S. \& Taylor, A. N. (1974). Vitam. Horm. 32, 299.

Wasserman, R. H. \& Taylor, A. N. (1969). In Mineral Metabolism, p. 321 [C. L. Comar and F. Bronner, editors]. London and New York: Academic Press.

Wasserman, R. H. \& Taylor, A. N. (1973). Triangle 12, I19.

Welty, J. C. (1962). The Life of Birds. Philadelphia: W. B. Saunders.

Wilson, H. R., Persons, J. N., Rowland, L. O. \& Harms, R. H. (I969). Poult. Sci. 48, 798.

Wood-Gush, D. G. M. \& Gilbert, A. B. (1965). 7. reprod. Fert. 9, 265.

Wood-Gush, D. G. M. \& Horne, A. R. (1970). Br. Poult. Sci. I1, 459 .

Wood-Gush, D. G. M. \& Kare, M. R. (1966). Br. Poult. Sci. 7, 285. 